Article

\title{
Sustainable Development through the Right to Access to Justice in Environmental Matters in China
}

\author{
Miao He ${ }^{1,2}$ \\ 1 Law Faculty/ Institute of Human Rights, Wuhan University, No. 299, Bayi Road, Wuchang Area, 430072, \\ Wuhan City, Hubei Province, China; miao.he@whu.edu.cn \\ 2 Institute of Human Rights Law, Law Faculty, Huazhong University of Science and Technology, 430074, \\ Wuhan City, Hubei Province, China
}

Received: 20 November 2018; Accepted: 4 February 2019; Published: 10 February 2019

check for updates

\begin{abstract}
Access to justice is an irreplaceable complementary right. Without enforcement, environmental law would be 'toothless' in practice. Recently, China has made some significant progress in protecting the relevant parties' right to access to justice in environmental matters. However, there are still some problems and challenges in the protection of this right in theory and in practice. To effectively realize this right, it is necessary to analyze the present situations and problems of the right in China from a legal perspective. This is done by introducing and analyzing the laws, regulations, policies, and practice concerning the right to access to justice in environmental matters in China. Specifically, this paper discusses the present situations of this right from several aspects. Based thereon, a brief problems analysis will be made. Some possible suggestions on how to better protect the right in China will be proposed from the perspectives of engaging, effectiveness and efficiency. These suggestions include empowering various parties with more capacity and possibilities; establishing a legal aid system and special fund; improving the exemption system and attorney fee transfer system; establishing a pre-litigation examination mechanism; and stimulating various parties' potential roles.
\end{abstract}

Keywords: China; right to access to justice; environmental matters; law; policy

\section{Introduction}

Access to justice is an irreplaceable complementary right; it shows itself as an inevitable legal remedy. From an environmental perspective, without enforcement, environmental law would be "toothless" in practice [1] (p. 129). From the perspective of environmental decision-making, access to justice refers to the right for members of the public to have access to review procedures where they can challenge decisions, acts, and omissions by public authorities and private persons [2] (p. 247).

There are not too many international instruments explicitly describing the right to access to justice. However, various universal legal instruments contain some provisions on the right to an effective remedy - for instance, from the angle of human rights instruments, Article 8 of the Universal Declaration of Human Rights and Article 2(3) of the International Covenant on Civil and Political Rights. From the angle of environmental protection instruments, the right to an effective remedy can be found in Chapter 8 of Agenda 21, Article 235(2) of the United Nations Convention on the Law of the Sea. Access to justice and effective legal remedies are crucial elements in both environmental protection and human rights protection. What is more, the right to a fair trial is also enshrined in universal human rights documents-for instance, Article 8 of the Universal Declaration of Human Rights and the United Nations Declaration on the Rights of Indigenous Peoples.

Some scholars [3,4] have suggested that the right to access to justice contains both substantial and procedural aspects. Briefly, the substantial aspect of the right to access to justice means getting justice, 
while the procedural aspect of the right to access to justice means the process of getting justice. The right to access to justice in this article only refers to the procedural aspect.

From the perspective of its ingredients, access to justice contains several factors-for instance, criteria for legal standing, burden of proof, review procedures, scope of the case, cost, available remedies and so on. From an external point of view, it is even more difficult to reach an agreement on what justice really is [5]. Justice is a dynamic concept with a complex set of merits; it ought to fluctuate with the changes of cultural, social, and historic conditions [6] (p. 139). Therefore, the process of getting justice largely depends on these conditions. The right to access to justice in environmental matters is the process of getting justice in the environmental field. The protection of the right to access to justice in environmental matters could be regarded as a human rights-based approach to conserve the environment.

Similarly, the problems in the protection of the right to access to justice in environmental matters are linked to the economic, social, cultural, legal, and political conditions prevalent in China. In the context of establishing a new socialist era with Chinese characteristics, China has made great progress in the protection of this right. However, there are still some problems and challenges in realizing this right. This article tries to answer the question of which recommendations could promote, or at least help, various parties to enjoy the right to access to justice in environmental matters in China. Particularly, this article tries to provide the answers to the following questions: (1) What are recent situations, including the theoretical basis, the relevant laws, regulations, policies, and practice, concerning the right to access to justice in environmental matters? (2) What are recent problems in the protection of this right from both theoretical and practical perspectives? (3) What are possible suggestions that could make a contribution to solving these problems in realizing the right?

\section{Methods}

The methods used are classical legal research methods. They are predominantly a desktop study and legal analysis, complemented with an analysis of case law. The research relied on the analysis of primary legal resources. These legal resources are selected national laws and policies which are directly related with environmental protection or human rights protection, for instance, the "Environmental Protection Law of the People's Republic of China" (2014 version), the "Measures on Right to Participation in Environmental Protection" (2015 version), the "Civil Procedural Law of the People's Republic of China" (2012 version), the "National Human Rights Action Plan of China" (2012-2015), and the "Interpretation of the Supreme People's Court on Several Issues concerning the Application of Law in Environmental Civil Public Interest Litigation Cases" (2015). The research also contains secondary legal resources (judgments from court cases in which primary sources have been applied in concrete situations), as well as an in-depth literature review in particular of research papers. It provides an overview of the main laws, regulations, policies, and practices relevant for the right to access to justice in environmental matters in China. The discussion part analyzes the present situations, including the plaintiff, the defendant, the methods for bearing legal liability, situations for accepting cases, and another eight factors. Based on the present situations, some problems in realizing the right to access to justice in environmental matters in China are discussed. The discussion part is mainly based on a literature study and practical situations. In the section with possible suggestions on solving the recent problems, the 3-E model, namely "engaging, effectiveness and efficiency", has been used as a way to structure the recommendations. All the legal resources and data sources are chosen to answer the research questions. 


\section{Results: Theory Basis, Laws, Regulations, Policies, and Practice Concerning the Right to Access to Justice in China}

\subsection{Theory Basis}

Environmental protection in China dates back at least to the Qin Dynasty (221-207 B.C.), when mountain areas were preserved as imperial hunting reserves and temple grounds were protected [7] (p.16). Confucianism teaches people to "live in harmony" with the universe and, hence, live in harmony with nature, holding that all things should be "loved" and "respected" and resources should be managed in a sustainable way [8]. In this context, environmental justice in China traditionally means the 'harmony' between humans and nature.

China's legal framework is rather young and started almost from scratch in the early 1970s after the country's attendance at the Stockholm Conference on the Human Environment [9] (p. 185). In the subsequent era of China's open policy and reform, initiated by Deng Xiaoping, the environmental legal regime began to develop, coinciding with a growing awareness of environmental issues [9] (p. 185). It is increasingly accepted that access to environmental justice refers to effective judicial and administrative remedies and procedures available to a person who is aggrieved or likely to be aggrieved by environmental harm [10] (p. 79). States should provide all possibilities to make sure the public can effectively access environmental justice.

\subsection{Legal and Policy Framework Concerning the Right to Access to Justice in Environmental Matters in China}

There is no provision explicitly referring to the right to access to justice in environmental matters in the Chinese Constitution. Only Article 41 of the Constitution of the People's Republic of China [11] declares that "[c]itizens of the People's Republic of China have the right to criticize and make suggestions on any State organ or functionary. Citizens have the right to appeal or sue or report the actions that violate the law or neglect the duty from any State authority or any official staff ( ... )".

Based on this Article in the Constitution, Article 6 of the "Environmental Protection Law of the People's Republic of China" [12] is regarded as the basic provision on access to justice in environmental matters in the existing legal system [13]. In addition, there are other direct provisions on the right to access to justice in environmental matters from laws or regulations on the environment (see Table 1).

Table 1. Direct provisions on the right to access to justice in environmental matters in Chinese environmental laws or regulations.

\begin{tabular}{|c|c|c|}
\hline Law & $\begin{array}{c}\text { Article } \\
\mathrm{No}^{\circ}\end{array}$ & Content \\
\hline \multirow{3}{*}{$\begin{array}{l}\text { Environmental Protection Law of } \\
\text { the People's Republic of China } \\
\text { (1989 version) [12] }\end{array}$} & 6 & $\begin{array}{l}\text { All units and individuals shall have the obligation to protect the } \\
\text { environment and shall have the right to report on or sue units or } \\
\text { individuals that cause pollution or damage to the environment. }\end{array}$ \\
\hline & 41 & $\begin{array}{l}\text { A unit that has caused an environmental pollution hazard shall } \\
\text { have the obligation to eliminate it and make compensation to the } \\
\text { unit or individual that suffered direct losses. A dispute over the } \\
\text { liability to make compensation or the amount of compensation may, } \\
\text { at the request of the parties, be settled by the competent department } \\
\text { of environmental protection administration or another department } \\
\text { invested by law with power to conduct environmental supervision } \\
\text { and management. If a party refuses to accept the decision on the } \\
\text { settlement, it may bring a lawsuit in a People's Court. The party } \\
\text { may also directly bring a lawsuit in a People's Court }(\ldots)^{\prime \prime} \text {. }\end{array}$ \\
\hline & 42 & $\begin{array}{l}\text { The limitation period for prosecution with respect to compensation } \\
\text { for environmental pollution shall be } 3 \text { years, counted from the time } \\
\text { when the party becomes aware of or should become aware of the } \\
\text { pollution losses. }\end{array}$ \\
\hline
\end{tabular}


Table 1. Cont.

\begin{tabular}{|c|c|c|}
\hline Law & $\begin{array}{l}\text { Article } \\
\mathrm{No}^{\circ}\end{array}$ & Content \\
\hline $\begin{array}{l}\text { Marine Environmental Protection } \\
\text { Law of the People's Republic of } \\
\quad \text { China (1999 version) [14] }\end{array}$ & 4 & $\begin{array}{l}\text { All units and individuals shall have the obligation to protect the } \\
\text { marine environment and have the right to watch for and report on } \\
\text { actions causing pollution damages to the marine environment by } \\
\text { any unit and individual, as well as on the act of transgression of the } \\
\text { law and neglect of duty by marine environment supervision and } \\
\text { administration personnel. }\end{array}$ \\
\hline \multirow{3}{*}{$\begin{array}{l}\text { Water Pollution Prevention and } \\
\text { Control Law of the People's } \\
\text { Republic of China (2008 } \\
\text { version) [15] }\end{array}$} & 85 & $\begin{array}{l}\text { The party whose rights and interests are damaged by a water } \\
\text { pollution accident is entitled to ask the party discharging pollutants } \\
\text { to eliminate the damage and make compensation for their losses ( } \\
\ldots \text {.. ). }\end{array}$ \\
\hline & 86 & $\begin{array}{l}\text { For a dispute over liability for damage or amount of compensation } \\
\text { in a water pollution accident, the administrative department of } \\
\text { environmental protection, the marine governing authority or the } \\
\text { administrative department of fishery may, according to the division } \\
\text { of functions and duties among them and in light of the request of } \\
\text { the parties concerned, settle it through mediation; if no agreement } \\
\text { can be reached upon mediation, the parties concerned may file a } \\
\text { lawsuit with the People's Court. The parties concerned may also file } \\
\text { a lawsuit with the People's Court directly without going through } \\
\text { the mediation procedure. }\end{array}$ \\
\hline & $87,88,89$ & $\begin{array}{l}\text { Some detailed information on the burden of proof, the number of } \\
\text { parties, liability for damage or the amount of compensation if } \\
\text { litigation happens. }\end{array}$ \\
\hline $\begin{array}{l}\text { Law of the People's Republic of } \\
\text { China on the Prevention and } \\
\text { Control of Atmospheric Pollution } \\
\text { (2000 version) [16] }\end{array}$ & 62 & $\begin{array}{l}\text { Any unit that has caused an atmospheric pollution hazard shall } \\
\text { have the responsibility of removing the hazard and of making } \\
\text { compensation to the units or individuals that have suffered direct } \\
\text { losses. Any dispute over the liability to make compensation or the } \\
\text { amount of compensation may, at the request of the parties, be } \\
\text { settled by the administrative department of environmental } \\
\text { protection. If a party refuses to accept the decision, it may bring a } \\
\text { lawsuit to a People's Court. The party may also bring a lawsuit to a } \\
\text { People's Court directly. }\end{array}$ \\
\hline $\begin{array}{l}\text { Law of People's Republic of China } \\
\text { on Prevention and Control of } \\
\text { Environmental Pollution by Solid } \\
\text { Waste Law (2004 version) [17] }\end{array}$ & 84 & $\begin{array}{l}\text { Units and individuals that have suffered damage from solid waste } \\
\text { pollution shall have the right to claim compensation according to } \\
\text { law. A dispute over the liability for damage and amount of } \\
\text { compensation may, at the request of the parties, be settled through } \\
\text { mediation by the administrative department for environmental } \\
\text { protection or the administrative department for supervision over } \\
\text { prevention and control of environmental pollution by solid waste; if } \\
\text { mediation fails, the parties may bring a lawsuit to a People's Court. } \\
\text { The parties may also directly bring a lawsuit to a People's Court. }\end{array}$ \\
\hline $\begin{array}{l}\text { Law of the People's Republic of } \\
\text { China on Prevention and Control } \\
\text { of Pollution from Environmental } \\
\text { Noise (1996) [18] }\end{array}$ & 61 & $\begin{array}{l}\text { Any unit or individual suffering from the hazards of environmental } \\
\text { noise pollution shall have the right to demand the polluter to } \\
\text { eliminate the hazards; if a loss has been caused, it shall be } \\
\text { compensated according to law. Any dispute over the liability for } \\
\text { losses or over the amount of compensation may, at the request of } \\
\text { the parties concerned, be mediated by the competent administrative } \\
\text { department for environmental protection or any other supervisory } \\
\text { and administrative department or institution in charge of } \\
\text { prevention and control of environmental noise pollution; if such } \\
\text { mediation fails, the parties may bring a lawsuit to a People's Court. } \\
\text { They may also directly bring a lawsuit to a People's Court. }\end{array}$ \\
\hline $\begin{array}{l}\text { Law of the People's Republic of } \\
\text { China on the Prevention and } \\
\text { Control of Radioactive Pollution } \\
\text { (2003) [19] }\end{array}$ & 59 & $\begin{array}{l}\text { Where radioactive pollution causes harm to people, civil liability } \\
\text { shall be borne in accordance with law. }\end{array}$ \\
\hline
\end{tabular}


Table 1. Cont.

\begin{tabular}{|c|c|c|}
\hline Law & $\begin{array}{c}\text { Article } \\
\mathrm{No}^{\circ}\end{array}$ & Content \\
\hline \multirow[t]{2}{*}{$\begin{array}{l}\text { Environmental Protection Law of } \\
\text { the People's Republic of China" } \\
\text { (2014 version) [20] }\end{array}$} & 57 & $\begin{array}{l}\text { Citizens, legal persons and other organizations shall be entitled to } \\
\text { report and complain about environmental pollution and ecological } \\
\text { damage activities of any units and individuals to competent } \\
\text { environmental protection administrations or other departments } \\
\text { with environmental supervision responsibilities. In the event that } \\
\text { the local people's government and its environmental protection } \\
\text { administrations or any other relevant departments fail to fulfill their } \\
\text { responsibilities in accordance with the law, any citizen, legal person } \\
\text { or other organizations have the right to report it to the competent } \\
\text { higher level governments or the supervisory department according } \\
\text { to law }(\ldots) \text {. }\end{array}$ \\
\hline & 58 & $\begin{array}{l}\text { For activities that cause environmental pollution, ecological damage } \\
\text { and public interest harm, social organizations that meet the } \\
\text { following conditions may file litigation to the People's Courts: (1) } \\
\text { having been registered at the civil affair department of people's } \\
\text { governments at or above municipal level with sub-districts in } \\
\text { accordance with the law; (2) specializing in environmental } \\
\text { protection public interest activities for } 5 \text { consecutive years or more } \\
\text { without any law-breaching records. Courts shall accept the } \\
\text { litigation filed by social organizations that meet the above criterion. } \\
\text { The social organizations that file the litigation shall not seek } \\
\text { economic benefits from the litigation. }\end{array}$ \\
\hline $\begin{array}{l}\text { Measures on Right to Participation } \\
\text { in Environmental Protection (2015 } \\
\text { version) [21] }\end{array}$ & 16 & $\begin{array}{l}\text { Environmental protection agencies can support environmental } \\
\text { social organizations who have a legal standing to go to a court by } \\
\text { various methods, including providing legal consultation, } \\
\text { submitting suggestions and cooperative investigation. }\end{array}$ \\
\hline
\end{tabular}

Based on what has been introduced, it is obvious that Articles 41 and 42 of the "Environmental Protection Law of the People's Republic of China" (1989 version), the "Law of People's Republic of China on Prevention and Control of Environmental Pollution by Solid Waste Law"(2004 version), and the "Water Pollution Prevention and Control Law of the People's Republic of China" (2008 version) made a bigger step forward in clarifying some detailed information on environmental civil litigation, such as the burden of proof, the parties of litigation, legal assistance, and so on. According to Article 58 of the revised "Environmental Protection Law of the People's Republic of China" (2014 version) [20], the legal standing for public interest litigation has expanded for NGOs since 1 January 2015. It is a good sign that reflects the developmental tendency of the legal standing for public interest litigation in China.

In practice, most of these forms of environmental litigation will result in civil liability, criminal liability, and administrative liability.

Some relevant provisions on access to justice in environmental matters in civil law, administrative law, and criminal law will be discussed in the following paragraphs. Article 98 of the "General Principles of the Civil Law of the People's Republic of China" (1986 version) [22] states "Citizens shall enjoy the right of life and health." Article 119 of the "Civil Procedural Law of the People's Republic of China" (2012 version) [23] explicitly declares that when a lawsuit is brought forward, the first condition which must be met is that the plaintiff must be a citizen, legal person or any other organization that has a direct interest in the case. The second condition is that there must be a definite defendant. As for civil law litigation, these restrictions might be useful, but regarding civil law litigation concerning environmental matters, these restrictions will not always be equal for the plaintiff and the defendant. In some cases, a victim who suffers from environmental pollution or an environmental project is indirect. What they have lost may be intangible. Instead of a specific person, normally a group of people would have suffered from environmental damage or an environmental project [24] (pp. 9-10) [25] (pp. 20-21). It is not always easy to identify the direct linkages between environmental damage and what victims 
really suffer from. In this sense, this would be one of the big obstacles for the realization of access to justice in environmental matters in reality. Notably, the draft Amendment of the Civil Procedural Law was submitted to the Standing Committee of the National People's Conference on 24 October 2011. It proposed that "the relevant agency, social groups can sue against the actions which harm social public interests, such as environmental pollution (... )" [26]. The only fly in the ointment is that "the relevant agency and social groups" in this amendment do not contain an individual, in other words, it does not provide explicit legal support for an individual in Civil Procedural Law [27] (p. 4). As indicated above, the scope of environmental cases in the amendment only focuses on environmental pollution.

Broadly speaking, environmental public interest litigation contains environmental civil public interest litigation and environmental administrative public interest litigation. The former aims to prevent or stop any harmful activities from enterprises and the latter intends to urge administrative agencies to take effective measures to protect the environment [28].

Concerning administrative procedural law, Article 2 of the "Administrative Procedural Law of the People's Republic of China" (1989) [29] explains that "[i]f a citizen, a legal person or any other organization considers that his or its lawful rights and interests have been infringed upon by a specific administrative act of an administrative organ or its personnel, he or it shall have the right to bring a suit to a People's Court in accordance with this law." According to this provision, some obstacles for access to justice in environmental matters need to be specified. Firstly, the "lawful rights and interest" in this provision would be infringed upon by a "specific" [30] administrative act. This means that a citizen, a legal person or any other organization would not have the right to bring a case to a People's Court if an administrative act is not specific [13]. Secondly, similar to civil law, this restriction on the qualification of the plaintiff also hinders a person or a unit from having real access to justice. Thirdly, in addition to the restriction for the plaintiff, it is not very clear who the defendant in some environmental administrative disputes is. These environmental administrative disputes would be excluded from a People's Court if there is an ambiguous defendant. Last but not least, the administrative act or decision from an administrative unit could lead to environmental harm, which would be serious and irreversible [13].

In addition to access to justice in environmental matters in civil and administrative law, criminal law could also be applied to punish anyone or any unit that seriously harms the environment. The "National Human Rights Action Plan of China" (2012-2015) [31] says that "China will improve the legal stipulations regarding judicial proceedings to guarantee the litigants' right to a fair trial." Although it mainly refers to criminal procedural litigation, it can be regarded as a sign for a broad entrance for access to court and a big progress for access to justice as well.

In addition, the "Interpretation of the Supreme People's Court on Several Issues concerning the Application of Law in Environmental Civil Public Interest Litigation Cases" (2015) [32] and "Notification of the Supreme People's Court, the Ministry of Civil Affairs and the Ministry of Environmental Protection on Implementing the System of Environmental Civil Public Interest Litigation" [33] clearly identify the legal standing in environmental civil public interest litigation, the procedures of litigation, and the methods for compensation [32].

Part 13 (from Article 284 to Article 291) of the "Interpretation of the Supreme People's Court on Application of 'Civil Procedure Law of the People's Republic of China'” (2014) [34] specifically focuses on the detailed information on public litigation cases, for instance, the conditions for accepting public litigation cases, competent courts, and terms of settlement. Article 7 of the "Opinions of the Supreme People's Court on Comprehensively Deepening the Reform of the People's Court: the Fourth Five Year Outline of the People's Court (2014-2018)" [35] indicates it is necessary to improve the system of public interest litigation. Article 30 of the "Opinions of the Supreme People's Prosecutors' Office on Deepening the Reform of Prosecutorial Work (2013-2017 Years' Work Plan)" [36] suggests it is necessary to establish the system for the public interest litigation brought about by the prosecutorial authorities. According to the "Pilot Program for Public Interest Litigation Brought by the Prosecutorial Authorities" [37] and "Decision of the Standing Committee of the National People's Congress on Authorizing the Supreme People's Prosecutorial to Carry Out Pilot Projects for Public Interest Litigation 
in Some Areas" (2015) [38], the Supreme People's Court released "Measures for the Implementation of the Pilot Program of Initiating Public Interest Actions by the People's Prosecutors' Office" (2015) [39]. Since then, the system for public interest litigation brought about by the prosecutorial authorities has been formally established. At the same time, public interest litigation work brought on by the prosecutorial authorities is being carried out throughout the country [40]. Notably, on 27 June 2017, the standing committee of the National People's Congress added Article 55.2 to the "Civil Procedure Law of the People's Republic of China" and Article 25.4 to the "Administrative Litigation Law of the People's Republic of China"; all these articles address the fact that prosecutorial authorities have a right to access to justice in certain circumstances [41] (p. 4). The third session of the Comprehensively Deepen Reform Commission from the central government approved the decision for the Supreme People's Prosecutors' Office to establish a public interest litigation prosecutor's office.

From these, we can see that the identification of the legal standing for the right to access to justice in environmental matters in China is greatly improved. Although there are still some limitations, an independent organ was identified to monitor actions that pollute the environment and destroy the ecosystem and to bring a lawsuit to the People's court under the right circumstances.

Remarkably, the "Guiyang Regulations on Promoting Ecological Progress" [42], which was regarded as the first local legislative document on environmental public interest litigation in China [25] (pp. 20-21), was implemented on 1 March 2010. The regulation stipulates that in order to protect environmental public interests, an individual or an environmental protection and management agency has the right to sue the related party (parties) who has (have) polluted the environment or destroyed natural resources. The plaintiff can ask the related party (parties) to stop the intervention, remove the obstruction, eliminate the dangers, and restore the environment or natural resources to their original state [43]. These tendencies reflect that Chinese governments from different levels began to realize the important role of environmental litigation in dealing with environmental matters.

\subsection{Right to Access to Justice in Environmental Matters in Practice in China}

In practice, there are four levels of People's Courts in China: the basic level; the intermediate level; the high level; and the supreme level. Each level of court is essentially responsible for political operatives at that level [44]. Local governments are responsible for their budgets and salaries [44]. This allows for strong local protectionism, and in the event of politically sensitive cases, courts often refuse to hear them, or leave them unresolved [44].

The People's Courts at different levels normally contain a civil tribunal, a criminal tribunal, and an administrative tribunal as well as other agencies. An environmental tribunal was established at the Supreme People's court in 2014 [45]. Since the first environmental tribunal in China was established at Qiaokou Area of the city of Wuhan in 1989, according to statistics in April 2017, there have been 296 environmental and resource tribunals in different levels of courts in China [46]. The scope of cases in environmental tribunals is traditionally limited to "four pests" (waste-water, waste-gas, industrial residue, noise) and "four pollution" types (air pollution, water pollution, marine pollution, and soil pollution). This means that other forms of environmental pollution, ecological damage, and disputes about natural resources are excluded from environmental tribunals [47] (p. 26). However, this situation has changed in recent years. In fact, according to the statistics from the Ministry of Environmental Protection of the People's Republic of China, there were 51,000 environmental disputes in 2005, increasing 30\% every year [48]. Other statistics show that there were more than 0.1 million environmental disputes in 2007 , but only less than $1 \%$ of these environmental disputes were brought before tribunals at different levels in China [49]. According to the statistics, there were 16,373 environmental resource criminal cases, 187,753 environmental resource civil cases, and 39,746 environmental resource administrative cases from July 2016 to July 2017 [46]. The Supreme People's court issued 11 typical environmental resource criminal cases, 4 typical environmental resource civil cases, and 2 typical environmental resource administrative cases [46]. These typical cases from the 
Supreme People's court provide an important guidance for hearing similar cases in the different levels of court in China.

In addition, there are other factors limiting the right to access to justice in practice in China-for instance, the traditional cultural background, the capacity of the plaintiff and the judges. Based on the traditional idea of "no litigation", the lack of independence by the judiciary has led Chinese citizens to use some of the other ways to seek justice, for instance, petitioning for justice, mediation, and protests [44].

Nevertheless, according to experience from both international and national theory and practice, litigation is an important method to solve environmental conflicts. It is encouraging to note that Chinese citizens are more frequently heading to court with the gravest pollution problems [50] (pp. 204-205), but people must be willing to challenge less obvious but nonetheless serious pollution and natural resource destruction [51] (p. 173). These are consistent with what environmental laws in China focus on. It is noteworthy that China, with its growing population, has acted in the past 5 years to establish and expand the system of environmental courts and tribunals [52]. Throughout the coming years, tribunals and courts will become increasingly more valuable to societies worldwide for resolving environmental conflicts and enforcing environmental safeguards [53] (pp. 369-374). This is particularly true in China, where citizens have experienced a growth in awareness of access to justice in the last decade.

In addition, environmental NGOs are playing an increasingly important role in environmental public interest litigation. The plaintiff in two notable cases was the All-China Environment Federation (ACEF) [54]. In 2009, the ACEF respectively sued Jiangyin Container Ltd. in the Jiangsu Province [55] and the Land Resources Bureau in the city of Qingzhen in the Guizhou province [56]. These two cases were accepted by the People's Courts in the two provinces. This shows that environmental NGOs had been accepted as a plaintiff in environmental litigation in practice before Article 58 of the revised environmental law was issued in 2014. Compared with an individual, environmental NGOs have their own advantages, especially in environmental litigation cases where there is a large group of victims that cannot choose a representative or lack the ability to go to a court $[25,57]$ (pp. 20-21). Notably, the first environmental public interest case [58] brought forth by an environmental NGO was accepted in 1 January 2015, and the environmental NGO ("Friends of Nature") won the litigation. Since then, more and more environmental NGOs choose to go to a court to pursue justice.

\section{Discussion: Present and Problems}

\subsection{Present Situations}

The right to access to justice in environmental matters was formally proposed in the academic field in 2006 in China [59] (p. 268). In order to deeply understand the present situations and problems of the right to access to justice in China, it is necessary to examine the plaintiffs, defendants, burden of proof, actionable range, contentious jurisdiction, prosecution deadline, and all other factors of the right.

\subsubsection{Plaintiff}

The key factor for access to justice in the environmental realm is the question of who has legal standing [60]. Legal standing is the ability of a person to show a sufficient legal interest in a matter to allow him or her to bring a case to court [60]. According to Article 58 of the "Environmental Protection Law of the People's Republic of China" (2014) [20], only environmental NGOs which meet the legal conditions could have the legal standing. According to statistics, around 700 environmental NGOs met these legal conditions by the end of September 2014 [61]. In addition to these environmental NGOs, with the support of the "Measures for the Implementation of the Pilot Program of Initiating Public Interest Actions by the People's Prosecutors' Office" (2015) [39], prosecutorial authorities also have the legal standing of the right to access to justice in environmental matters. 
Environmental public interest litigation is an important way to realize the right to access to justice in environmental matters; this can be divided into environmental civil public interest litigation and environmental administrative public interest litigation. As discussed above, according to Article 55 and Article 119 of the "Civil Procedural Law of the People's Republic of China" [23], the legal standing of the plaintiff in environmental matters shall follow the principle of "direct interest relationship". In practice, the relevant authorities and organizations may be various, for instance, a social organization, the People's Prosecutors' Office [61], the authorities who are in charge of sea protection [62], environmental protection authorities [63], natural resources management authorities [64], volunteers [65], environmental non-governmental organizations [66], and governments [67]

\subsubsection{Defendant}

As for the defendant, there is no provision in the relevant laws and regulations that specifically identifies any restriction for the defendant. This means that any subject who conducts the relevant actionable behavior would be the defendant in environmental litigation. In practice, the defendant in environmental litigation would be various parties. According to empirical analysis on the environmental civil public interest litigation accepted by the different levels of the People's court in 2015, in addition to individuals and enterprises, public institutions (Guizhou University), village committees (Magu village), local governments (the People's government in Longde county) and administrative machinery (Broadcasting and Entertainment Bureau in Shangjie county) were the defendants in environmental public interests litigation [68] (pp. 16-33).

\subsubsection{Burden of Proof}

It is quite difficult to bear the burden of proof in environmental cases for the reason that these cases have latent and long-term characteristics, especially in environmental pollution cases. For instance, to bear the burden of proof in marine environmental pollution cases requires scientific and professional knowledge and professional expert support. No matter who would bear the burden of proof, even with support from professional experts, it is still a great challenge to collect all the possible proof and to appropriately conserve all the possible proof until the court hearing. Although 'reversion of burden of proof' would bring a certain amount of convenience for lawsuits, the situations and the results of all possible proof would largely decide the result of the lawsuit in environmental pollution cases. If the plaintiff lacks professional knowledge and does not get support from experts, it is quite difficult for them to propose some appropriate and important appeal points. In this context, even if they have a legal standing for the right to access to justice, this lawsuit would be meaningless to improving the environment.

\subsubsection{Actionable Range}

The "Environmental Protection Law of the People's Republic of China" (2014) [20] declared that any action 'destroying the environment' and 'polluting the ecosystem', which has the potential to 'harm public interests', is actionable, no matter the field or form. How to judge whether these interests were harmed or would be harmed is a key issue. These 'public interests' specifically contain 'economic public interests' and 'ecological public interests'. Comparatively speaking, it would take a long time to show that 'ecological public interests' are harmed. The possibilities to 'harm public interests' would be considered in the actionable range. Article 58 of the "Environmental Protection Law of the People's Republic of China" [20] addresses three formal requirements; there is no requirement for a substantial relationship between the plaintiff and the cases. Legislators may think that if the environmental NGOs are meeting the three formal requirements, the litigation brought by them cannot be refused by the People's Court. Article 4.2 of the "Interpretation of the Supreme People's Court on the Application of the Relevant Laws in Environmental Civil Public Interest Litigation" (2015) [69] suggests that the public interests in the litigation brought forward by environmental NGOs should have a close 
relationship with its purpose and business scope. In practice, the litigation accepted by the People's Court does not have a direct relationship with the purpose and the business scope of the plaintiff. For instance, on 21 July 2016, because of the noxious runway in Beijing Wanxiang Kindergarten, China Biodiversity Conservation and Green Development Foundation vs Beijing Wanxiang Kindergarten was accepted by the People's Court [70]. In addition to this, China Biodiversity Conservation and Green Development Foundation introduced other environmental public interest litigations for various reasons-for instance, water pollution [71], marine protection [72], air pollution [73], soil pollution [74], and threatened plant protection [75]. From these, we can see that the restriction in the relevant laws for environmental NGOs' business scope is not very strict in practice.

\subsubsection{Jurisdictional Limits}

Jurisdictional limits contain the subject matter jurisdiction of courts at different levels and territorial jurisdiction. Regarding the subject matter jurisdiction of courts at different levels, Article 6 of the "Interpretation of the Supreme People's Court on the Application of the Relevant Laws in Environmental Civil Public Interest Litigation" (2015) [69] indicates that environmental civil public interest litigation shall be under the jurisdiction of the People's Court at or above intermediate level and the People's Court at the primary level upon approval of the Supreme Court. In addition, the Supreme Court has set up a special tribunal for environmental cases since 2014.

As for territorial jurisdiction, the "Interpretation of the Supreme People's Court on the Application of the Relevant Laws in Environmental Civil Public Interest Litigation" (2015) [69] explains that relevant cases shall be under the jurisdiction of the People's Court where the damaging action took place or where the damaging result of the action was identified or where the defendant is located. The fourth Plenary Session of the $18^{\text {th }}$ CPC Central Committee addresses that it is necessary to establish a special court across administrative regions. If the relevant cases refer to the environment across more than one administrative region, these will be under the jurisdiction of this special court to make sure that the court will consider the whole environmental impact for all the related regions-for instance, a protected area across several administrative regions or a long river across several administrative regions.

\subsubsection{Time Limit for Prosecution}

Article 42 of the "Environmental Protection Law of the People's Republic of China" (2014 version) [20] clarifies that the validity period for prosecution with respect to compensation for environmental pollution damage shall be 3 years, counted from the time when the party becomes aware of or should become aware of the damage. Considering that some harmful consequences have long-term, concealment factors and evidence collection or damage identification would last a long time, there is no strict restriction for the prosecution deadline in practice. There were six special public interest litigations in 2015 [68] (pp. 16-33). The defendants, who had already been punished based on criminal law, were prosecuted again for the public interest. Although some of these defendants were already in prison, the People's Court still accepted these litigations and approved that the defendants shall provide a great amount of compensation.

\subsubsection{Prepositive Procedure}

There is no clear prepositive procedure for environmental litigation. Article 12 of the "Interpretation of the Supreme People's Court on the Application of the Relevant Laws in Environmental Civil Public Interest Litigation" [69] proclaims that '[a]fter accepting the environmental civil public interest litigation, the People's Court shall, within 10 days, inform the relevant department who is responsible for environmental supervising and managing the defendant's behavior.' This shows that only once the litigation is accepted does the People's Court have an obligation to inform the relevant department. There is no relevant provision in any law and regulation for this issue in administrative public interest litigation for environmental matters. 


\subsubsection{Methods for Bearing Legal Liability}

There is no provision on methods for bearing legal liability for environmental litigation in the "Environmental Protection Law of the People's Republic of China" (2014 version) [20]. Legislators may think that 'civil litigation' automatically applies the relevant provision in the civil law. However, the plaintiff's request is often difficult to be realized by traditional civil liability. Regarding this issue, Article 18 of the "Interpretation of the Supreme People's Court on the Application of the Relevant Laws in Environmental Civil Public Interest Litigation" (2015) [69] explained that the plaintiff can request that the defendant fulfill their due obligations in six ways, including stopping infringement, removing obstacles, eliminating danger, restoring the original state, compensating for the loss, and apologizing. This was designed according to the civil law logic of "harm-loss-compensation". Articles 19 and 24 of the "Interpretation of the Supreme People's Court on the Application of the Relevant Laws in Environmental Civil Public Interest Litigation"(2015) [69] specifically describe the identification and implementation of these obligations and try to bring some special environmental obligations into traditional civil obligations, for instance, introducing the disposal expenses for environmental accidents into 'stopping infringement, eliminating obstruction, eliminating danger', restoring the ecosystem and paying an ecological restoration fee into 'restoring the original state', and bringing the loss of ecological services into 'compensating for the loss'. In addition to these, Article 25 of the "Interpretation of the Supreme People's Court on the Application of the Relevant Laws in Environmental Civil Public Interest Litigation" (2015) [69] approves the effectiveness of the conciliation agreement or the settlement and requires less than 30 days announcement and court examination. Generally speaking, any defendant in environmental matters who has any negative impact on the environment shall bear the cost of restoring the ecosystem or paying the compensation.

\subsubsection{Transfer of Litigation Costs}

There is no provision on transfer of litigation costs in the "Environmental Protection Law of the People's Republic of China" (2014 version) [20]. It is noted that Article 22 of the "Interpretation of the Supreme People's Court on the Application of the Relevant Laws in Environmental Civil Public Interest Litigation" (2015) [69] declares that if the plaintiff requests that the defendant bear the costs of inspection, appraisal, reasonable attorney fees, and other reasonable expense for litigation, the People's Court may support them in accordance with the relevant law. The litigation costs in environmental matters can only be transferred from the plaintiff to the defendant. In practice, the defendant is normally required to bear the costs for litigation. Article 33 of the "Interpretation of the Supreme People's Court on the Application of the Relevant Laws in Environmental Civil Public Interest Litigation" (2015) [69] addresses that if the plaintiff has difficulty in paying the litigation costs and applies to the People's Court for postponement of the fee, in accordance with the regulations, the People's Court shall grant permission. According to Article 44 of the "Measures on the Payment of Litigation costs in People's Republic of China" (2006) [76], any parties that have genuine difficulty in paying litigation costs may, according to the relevant rules, apply to the People's Court for deferment or reduction of the payment or for an exemption. The exemption from paying litigation costs only applies to natural persons. In order to guarantee the environmental public interests, if an environmental NGO accesses justice and loses a lawsuit, the People's Court shall regard this environmental NGO as a natural person and exempt them from paying the litigation costs.

\subsubsection{Excessive Litigation Control}

It is subconsciously accepted that environmental NGOs, which meet the requirements of the relevant environmental laws, would not need excessive litigation control. In practice, more than 700 environmental NGOs have legal standing in China. In fact, only nine environmental NGOs individually or jointly accessed the court for 38 environmental cases in 2015 [68] (pp. 16-33). This means that only around 1/78 (9/700) environmental NGOs would choose to go to court to seek justice. 
These environmental cases only emphasize 'ecological damage', rarely referring to the legal remedy of the social subjects, such as local peoples and individuals. Actually, many illegal environmental acts are continuing to negatively impact the local peoples and individuals; however, they are rarely entered into judicial proceedings. Normally, citizens who have been negatively affected by the illegal environmental acts have a strong urge to sue those responsible, but in fact, they do not have the legal standing of the right to access to justice in environmental matters.

\subsubsection{The Right of Disposing}

The right of disposing mainly contains compromise and settlement during litigation and applying for nolle prosequi. If an environmental litigation becomes resolved, it would speed up the judicial process of cases, saving judicial resources and facilitating the execution of cases. This is allowed by the relevant laws and legal interpretations with the condition that environmental public interests must be protected. Regarding the application of nolle prosequi, if the defendant pollutes the environment or destroys the ecosystem and the fact is clear or the evidence is certain, nolle prosequi applied by the plaintiff is forbidden. Nolle prosequi would only be allowed in certain circumstances, for instance, if there is a lack of evidence or the defendant confesses his/her fault and actively restores the natural ecosystem. Article 19 of "Interpretation from the Supreme People's Court and the Supreme People's Procuratorate on Some Issues of Applicable Law for Supervising Public Interests Litigation Cases" (2018) [77] explains that for civil public interest litigation cases, the People's Court shall allow nolle prosequi with the condition that all the claims from the People's Prosecutors' Office are realized.

\subsubsection{Situations for Accepting Cases}

According to the relevant environmental laws, the People's Court would accept environmental lawsuits in two situations: (1) an act would affect the environment, but this act is not illegal; (2) an act is illegal, but there is no actual damage. As for environmental public interest litigation, it would be accepted by the People's Court on the condition that the potential defendant would harm or has harmed public interest. However, how to define the 'public interest' is still a problem in theory and in practice. For instance, a water conservancy project may benefit public interest, but it will obviously change or even destroy the environment. According to the relevant environmental laws, it seems that the People's Court 'should' accept this case if any plaintiff sues this project at the People's Court. This might be a possibility in theory. In practice, it is quite difficult to realize.

Since there is no 'persistent' requirement in the relevant environmental laws, generally speaking, it is easier to deal with cases where an act has been committed than with cases where an act is being committed. In practice, according to empirical analysis of environmental public interest litigation in 2015, a large number of cases are 'prosecuting' for 'old cases', in which the act has been committed or the defendants have been punished by the relevant laws [68] (pp. 16-33).

\subsection{Problems Analysis:}

The laws and regulations mentioned above provide the legal basis for the right to access to justice in environmental matters in China. There are still some problems in realizing the right to access to justice in environmental matters in China.

Firstly, the subject scope of the plaintiff is relatively narrow. The key problem is that the relevant laws and regulations do not empower individuals to have a legal standing of the right to access to justice in environmental matters. Any action that harms the environment would negatively impact individuals, especially local peoples. In fact, though, they do not have a real right to access to justice in environmental matters. Although some environmental NGOs and the People's Prosecutors' Office could stand for local peoples to go to court, the key issue is that if environmental NGOs and the People's Prosecutors' Office lose a lawsuit, the affected individuals would normally bear the loss in practice. This is certainly not fair for them. If a prosecutor, who stands for the government, would bear the real loss, this could cause the possible right-holders to just sit back and leave others to find a 
way out. If a prosecutor loses a lawsuit for the reason that the prosecutor neglected their duty, this is also not fair for the affected individuals, especially when the affected individuals do not have the legal standing for the right to access to justice.

Secondly, capacity building is a key problem. Due to the short history of the research and education on environmental law in China, capacity-building is a critical problem not only for a potential plaintiff, such as individuals or NGOs, but also for lawyers and judges [78] (pp. 163-169). As for a potential plaintiff, these capacities contain the awareness to guarantee their affected interests, the ability to ask for possible financial support, the specialized skills to collect environmental information required as evidence in the litigation, and the ability to preserve possible evidence. It will take some time for lawyers and judges to acquire relevant knowledge and practical experience in litigation [78] (pp. 163-169). As for judges, how to judge whether the plaintiff's potential interests were harmed or would be harmed is a challenge in practice. How to appropriately define a 'direct interest relationship' in civil lawsuits and a 'legal interest relationship' in administrative lawsuits is another challenge for judges. For instance, environmental pollution may indirectly affect a certain group of people in the long term. The number of this group of people may be uncertain and various. It is difficult for this certain group of people to access justice for environmental pollution [79] (p. 13).

Thirdly, a Court or a judge may lack the necessary motivation to solve a particular environmental dispute because of the environmental dispute's characteristics [78] (pp. 163-169). For instance, environmental pollution may intangibly and consistently damage a person or an ecological system for a long time, creating challenges for assessing the quantum of damage [78] (pp. 163-169). In practice, a judge might be worried about this long process which could affect his/her working efficiency [80] (p. 154).

Fourth, there is insufficient public participation in environmental matters in China. The first instrument evidencing a political will to provide for public participation appeared in a 1973 document in China entitled "Several Opinions on the Protection and Improvement of the Environment" [6] (p. 145). In 1996, the central government in China definitely set out to "establish a public participation mechanism, develop social group function, and encourage the public to participate in environmental protection, impeach and reveal all kinds of behavior against the environmental laws" in the "Decision of the State Council on Several Issues Concerning Environmental Protection" [81] (p. 20). In spite of the progress on public participation in environmental matters in China, compared to some developed counties, there are still limitations for public participation. In fact, there are perhaps hundreds of theories as to what democracy means, and "elite democracy" and "participatory democracy" are dominant [82] (p. 274). The hypothesis of "elite democracy" is that governments know better than the public and that public participation would lead to a long period of discussion and communication without any fruitful results. The theory of "elite democracy" might represent what democracy means in China. Owing to the greater pressure of the urgent need for economic development and the educational level of the public in China, it is obvious why there is less public participation there than in developed countries [82] (p. 275). The government at different levels in China had to pay more attention to efficiency than to relative fairness [82] (p. 275). However, with the rapid development of the economy and the increasing growth of the education level of the public, it is the right time to learn how to stimulate the potential roles of the public [82] (p. 275).

Fifth, there is a lack of a comprehensive legal aid system in environmental matters in China. As indicated above, a potential plaintiff would not collect all possible evidence and preserve it without support from professional experts. Even if a potential plaintiff could find the right expert to help, whether he/she is able to pay for the right expert or not is a prerequisite for enjoying the right to access to justice in environmental matters. More importantly, those who live in poverty-mostly in rural areas-have limited access to legal services [83]. The concentration of financial and human resources in urban areas has excluded much of the rural population from access to lawyers and the courts [83], even though, in many instances, serious environmental damage occurs in rural areas. 
Sixth, it is not easy to solve potential conflicts in different regions for access to justice in practice. For instance, if there is any pollution in an inter-regional river, the problems cannot be solved within one region [78] (pp. 163-169). In practice, different courts in different regions could render different judgments in essentially similar cases on the basis of different regional conditions [78] (pp. 163-169).

\section{Possible Suggestions}

As introduced and discussed above, some features of the right to access to justice in environmental matters in China can be summarized below. Firstly, the plaintiffs are becoming various in practice. Secondly, regarding the litigation process, it would normally last a long time during the first trial, second trial, and supreme People's Court for retrial, consuming a large amount of human, financial, and material resources. Thirdly, with regard to the litigation outcome, what the defendant needs to bear is much less than the loss of the environment. Fourth, from the perspective of the developmental tendency, environmental NGOs, individuals, and the People's Prosecutors' Office are playing increasing roles in environmental litigation. Based on the present situations and problems of the right to access to justice in environmental matters, some possible key suggestions on how to improve this right will be proposed below.

\subsection{Engaging}

5.1.1. Empowering Environmental NGOs Creates More Possibilities to Enjoy the Right to Access to Justice in Environmental Matters

As discussed above, environmental NGOs, which meet the requirements of Article 58 of the revised environmental law, are able to have a legal standing for the right to access to justice in environmental matters. One of the key requirements is that environmental NGOs need to specialize in environmental public interest activities for 5 consecutive years or more and have no law violation records. This strict "five consecutive years or more" excludes some environmental NGOs, which are willing to go to court to protect environmental public interests. Some environmental NGOs may change their name or change their original registered place for some reasons, so how to judge the " 5 consecutive years or more" is a key issue in practice. It is necessary to empower more environmental NGOs to have the possibility to enjoy the right to access to justice in environmental matters with the condition that they really care about the environmental public interest. In this way, the potential enthusiasm and roles of environmental NGOs in environmental matters would be largely stimulated.

\subsubsection{Empowering Judges Creates More Capacity}

Laws on paper need to be put into practice. With the increasing number of environmental litigations in the People's Court and the increasing establishment of environmental tribunals in China, more professional judges in environmental matters are urgently needed in China. In fact, whether the related party could really enjoy the right to access to justice in environmental matters or not largely depends on the judgement from judges in the People's Court in China. Whether judges have enough capacity is a key issue. Judicial capacity-building is best undertaken by judges and for judges [53] (pp. 369-374). Courts supervise their own continuing judicial education, and thus ensure their independence, autonomy, and credibility with all parties that appear before the courts [53] (pp. 369-374). Actually, the judgement from judges will be affected by several factors. For instance, some environmental litigations could last a very long time for the reason that it is difficult to collect and preserve evidence; judges may therefore think about how to quickly settle this kind of lawsuit for the reason that they would care more about their own workload statistics in the Court. Another example is that any party who has a legal standing for the right to access to justice in environmental matters can sue a company which is in violation of environmental regulations [84]. Even if a polluting company loses a law suit, it can still escape legal punishment, as a large number of court orders have 
not been enforced in China [84]. Thus, the capacity for judges refers not only to their professional improvement but also to their independence from outside factors.

\subsubsection{Empowering Citizens with the Right to Access to Justice in Environmental Matters}

In order to let any related party have an opportunity to achieve access to justice, in addition to environmental NGOs and the People's Prosecutor, it is necessary to empower individuals with the right to access to justice in environmental matters in China. Some problems need to be considered. Firstly, when is it an appropriate time to empower individuals to have a legal standing for the right? Secondly, how many individuals could have a legal standing for the right? All the individuals or a group of them? If all individuals in China could have a legal standing, it would be a big challenge for lawyers, judges, environmental tribunals, the legal aid system, and social resources with the present situation in China. If only a group of individuals could have a legal standing, the third problem would be how to set requirements for individuals. As discussed above, one of the key requirements for environmental NGOs is " 5 consecutive years or more". As a start, should we set a similar requirement for individuals with the present situation in China?

Undoubtedly, to empower every citizen, the equal right to access to justice in environmental matters is an important tendency in China.

\subsection{Effectiveness}

\subsubsection{Establishing a Legal Aid System in Environmental Matters}

Since environmental litigations are normally complicated and it is difficult to collect and preserve evidence, these litigations would be difficult to process without support from professional lawyers and experts. Without proper legal assistance, Chinese citizens may remain without adequate access to the judicial system [51] (p. 173), even if empowered with an equal right to access to justice.

The "Regulations of the People's Republic of China on Legal Aid", which was issued in 2003, provides basic and important support for establishing a legal aid system. According to the regulations, the legal aid would be provided for three kinds of objects: (1) poor or vulnerable people in civil or criminal litigation; (2) disabled people or juveniles; (3) a defendant would be sentenced to death without a lawyer in criminal litigation. However, the regulations do not directly contain any clause for an environmental litigation. Only the "Law of the People's Republic of China on Prevention of Environmental Pollution Caused by Solid Waste" (20014 version) [17] encourages the relevant legal aid authorities to provide legal assistance for the subjects who suffered from solid waste pollution. In 2013, the third plenary session of the $18^{\text {th }}$ Central Committee of the Chinese Communist Party defined that it is necessary to improve the legal aid system in China. Until December 2017, the "Suggestions on How to Improve the Legal Aid System" had been issued in 29 provinces in China. However, there is not yet any direct suggestion of legal aid for environmental litigation. To guarantee citizens' right to access to justice in environmental matters, it is necessary to establish the legal aid system for environmental litigation in China.

In practice, the legal aid center was established in the Ministry of Justice in 1996. After this, some legal aid centers were established in the provincial level. The legal aid centers not only provide legal and financial support for litigation, but also encourage law firms and NGOs to actively participate in civil public interest litigation proposed by citizens. In fact, some warm-hearted lawyers would like to actively provide legal aid for public interest litigation proposed by the vulnerable groups. In fact, the number of government lawyers providing legal aid remains inadequate to meet the demand [44]. In many rural areas, unlicensed, self-trained individuals are the only available legal advisers [44]. Public interest law firms, usually based within universities or law schools, also offer legal services, but these services are limited [44]. In most cases, the vulnerable groups are too poor to pay lawyers or to ask for legal services. In this sense, non-profit legal assistance will be an important contributor to the effective operation and legitimacy of an environmental court system [50] (pp. 204-205). As indicated above, 
China has embraced legal assistance to a dramatic degree in the last decade. By the end of 2002, China had more than 2400 legal aid offices, the overwhelming majority of which were State-funded [85]. Official statistics state that legal aid lawyers handled some 180,000 cases in 2002, a $28 \%$ increase on the prior year [85]. By the end of 2012, official statistics state that there were 3236 legal aid centers in China, providing legal aid for more than 1.02 million cases [86]. Some relevant institutes were increasingly set up these years, for instance, the Centre for Legal Assistance to Pollution Victims mentioned in the previous section. Out of a total of 135 cases in which aid was provided by the Centre for Legal Assistance to Pollution Victims (hereinafter, as "CLAPV") between November 1999 and October 2009, 70 cases have been resolved [87]. Of these 70 cases, the CLAPV won 32 cases and lost 26 cases [88]. Just to illustrate, in the case of 1721 People vs Rongping Chemical Plant [89], the High People's Court in Fujian Province awarded the plaintiffs 684,000 Yuan (around 86.4 thousand euro) [90] for damage caused to their crops by the chemicals emanating from the plant [50] (pp. 204-205). These tendencies reflect that Chinese governments at different levels began to steer disputes into the courts. These developments also demonstrate both the significant progress over the past decade in making the courts more accessible, and also some of the continuing barriers to those seeking redress through law [85].

\subsubsection{Establishing a Special Fund for Litigation in Environmental Matters}

As indicated above, one of key problems for the relevant parties to enjoy the right to access to justice is the lack of financial support. This gap could largely be filled by establishing a special fund for environmental litigation. The next problem is how to solve the relevant problems in establishing the special fund. The financial source of this fund could be the government, companies, enterprises, or individuals. As for the process of establishing the fund, the relevant administrative organs, for instance, a civil administrative department, shall be in charge of reviewing application documents. After the review, the special fund could be registered and supervised by the relevant government agency. The management system for this fund can be divided into two systems. One system is responsible for exploring the source of the fund and operating the fund, while another one is in charge of examining the application on the environmental public interest litigation fund and deciding whether to provide subvention or not [91]. In addition to these, it is also necessary to set up strict grant application criteria, especially examining the character of the case, the parties, and the legitimacy of the exercise of the right of action. In practice, the first "environmental public interest litigation support fund" was established by an environmental non-governmental organization, "Friends of Nature", in January 2015, and the famous Nanping case was supported by this fund [92] (p. c02).

\subsubsection{Improving the Exemption System and Attorney Fee Transfer System for Litigation Costs}

As indicated above, if an environmental litigation does not have strong support from a professional lawyer, the litigation will not be processed easily. Since attorney fees for professional lawyers are quite expensive, one of the key challenges for the plaintiff to enjoy the right to access to justice in environmental matters is attorney fees. It is necessary to improve the exemption system and attorney fee transfer system for environmental litigation in China, not only to allow the plaintiff to enjoy the right to access to justice, but also to attract and encourage competent lawyers to actively participate in environmental litigation.

According to Article 4 of the "Measures on the Payment of Litigation costs in People's Republic of China" (2006) [76], the State provides judicial relief to parties who really have difficulties in paying litigation costs, guarantees lawful exercise of their litigation rights, and safeguards their lawful rights and interests.

Improving the exemption system means that the plaintiff in the litigation could not submit the case acceptance fee and application fee and the People's Court decides who will bear the relevant costs. If the defendant loses the lawsuit, the defendant will bear the costs; while if the plaintiff loses the lawsuit, the costs will be better undertaken by the State or the special fund mentioned above. In this way, the financial burden for the plaintiff can largely be alleviated. 


\subsection{Efficiency}

\subsubsection{Establishing a Pre-Litigation Examination Mechanism}

Law really cannot be understood without understanding the culture in which it sits [93] (p. 452). As indicated above, Chinese traditional ideas have a negative view on litigation. Confucian [94], Legalism [95], and Taoism [96], as the three main different schools of traditional ideas that strongly influence future generations in China, all pursue no litigation [97] (p. 69). In this context, it is necessary to establish a pre-litigation examination mechanism. This mechanism is not only for preventing excessive litigation and reducing the burden of the judicial organs, but also for supervising administrative organs in the performance of their duties. This means that if any party who has a legal standing wants to guarantee his/her possible interests or public interests, his/her claims should be examined and the relevant evidence must be investigated by an independent and professional organ in this mechanism. After the examination, the plaintiff can get the legal support from this organ to supervise the relevant administrative authorities to perform their duties within a certain period. This supervision would be direct, timely, and effective. If the relevant administrative authorities, for instance, prosecutors, do not perform their duties on time, the plaintiff could directly report this to the independent and professional organ.

In fact, a pre-litigation examination mechanism is also important for the People's Prosecutors' Office. According to the statistics, there have been more than 40 thousand administrative pre-litigation suggestions from the Prosecutorial Authorities in China in the last 2 years, 92.4\% of which were adopted by the relevant administrative organizations [98]. Whether these suggestions are really suitable for the cases or not is a key issue.

\subsubsection{Stimulating Various Parties to Actively Participate in Environmental Litigation in Various Forms}

It is necessary to stimulate various parties to actively participate in environmental litigation in various forms. The potential enthusiasm and roles from various parties would make great contributions to protecting the environment.

Recently, in order to stimulate various parties to actively participate in environmental litigation, the Supreme People's Court in China called for the Supreme People's procurators, the Ministry of Justice, the public security organ, the Ministry of Land and Resources, the Ministry of Ecology and Environment, and the relevant authorities to cooperate together to issue judicial interpretations, do the relevant research, and establish an information-sharing platform [46].

As indicated above, environmental NGOs play an increasing role in environmental litigation in China. It is also necessary to expand multiple forms of this participation for environmental NGOs. The first and foremost step is to empower them with the right to environmental information. Environmental information, for instance, environmental monitoring information or data, is the main source of evidence in environmental litigation. Normally, only environmental administrative authorities have this environmental information for the reason that this information can only be collected and updated by professional equipment and specialized persons with professional skills. Individuals or environmental NGOs cannot obtain the information until the relevant authorities deliver this information. Guaranteeing the environmental NGOs' right to environmental information is a prerequisite for safeguarding them to enjoy the right to access to justice in environmental matters. Secondly, environmental NGOs are able to contribute to disseminating environmental concepts, publishing environmental information, improving citizens' environmental awareness, and the relevant aspects. Thirdly, environmental NGOs can play an important role in supervising the implementation of the judges' adjudging in environmental litigation. As indicated above, environmental litigation is a long and complicated process, and the judges' adjudging is not the end. How to implement or realize this adjudging is a key step. In practice, environmental NGOs contribute a lot in supervising the implementation of the judges' adjudging in Qingzhen City, Guizhou Province. Under the supervision of environmental NGOs, some enterprises in Qingzhen City, as a defendant, are actively taking various 
measures to implement the judges' adjudging, for instance, cleaning up the environment and restoring the ecosystem. It is necessary to learn this lesson from Qingzhen City to establish a national monitoring system for environmental NGOs to supervise adjudging from environmental litigation.

In addition, establishing a winning awards system would also be a method to stimulate all the relevant parties to actively participate in environmental litigation. The plaintiffs in environmental litigation need to make great efforts in several aspects to sue the defendants. The defendants are normally enterprises, factories or the government. The plaintiffs confront these strong defendants for the public interest. This award-winning system will not only serve to stimulate the potential enthusiasms and roles of the plaintiffs in environmental litigation, but also to stimulate all the relevant parties to guarantee the public interest.

\section{Conclusions}

Generally speaking, the legal protection for the right to access to justice in environmental matters in China has made great progress from both theoretical and practical perspectives in recent years. However, there are still some key challenges in realizing this right. These challenges can be summarized as: (1) the subject scope of the plaintiff is relatively narrow; (2) capacity building is a key problem not only for a potential plaintiff, but also for lawyers and judges; (3) a Court or a judge may lack the necessary motivation to solve a particular environmental dispute; (4) insufficient public participation in environmental matters; (5) there is a lack of a comprehensive legal aid system in environmental matters; (6) there are some potential conflicts in different regions for access to justice in practice. We cannot expect these problems to be solved in a single method within a short period. Possible solutions to these challenges are to first empower environmental NGOs and citizens with more possibilities to enjoy the right to access to justice in environmental matters and to empower judges with more capacity. Establishing a legal aid system and special fund in environmental matters and improving the exemption system and attorney fee transfer system for litigation costs is the second step to promote effectiveness of the realization of the right to have access to justice in environmental matters. The third step is to establish a pre-litigation examination mechanism and to stimulate various parties to actively participate in environmental litigation in various forms, which would promote efficiency. The 3-E model (Engaging-Effectiveness-Efficiency) would help to promote the realization of the right to access to justice in environmental matters in China. The next problem would be how to deeply realize and implement this 3-E model in practice in China. To what extent can this 3-E model help in realizing the right to access to justice in environmental matters in China? These still need further research. It is worth noting that the realization of the right to access to justice in environmental matters could promote the implementation of the environmental laws and regulations in China.

Acknowledgments: The author thanks three anonymous reviewers for their valuable comments. The author is also grateful for the valuable comments from the Academic editors, Timo Koivurova and Volker Mauerhofer, and great efforts from assistant editor Juliet Zhong. The study was supported by the Youth Project (Grant No. 18 YJC820023) of the Ministry of Education, China and the General Financial Grant from the China Postdoctoral Science Foundation (Grant No.: 2016M592359), China. The study was also supported by "the Fundamental Research Funds for the Central Universities", China.

Conflicts of Interest: The author declares no conflict of interest.

\section{References}

1. Kostic, M. The Right of Access to Environmental Information in the Sense of the Aarhus Convention: European Streams and Legal Framework in Serbia and Montenegro; CPRINT: Beograd, Serbia, 2006.

2. Ebbesson, J. Access to justice at the national level: impact of the Aarhus Convention and European Union law. In The Aarhus Convention at Ten: Interactions and Tensions between Conventional International Law and EU Environmental Law; Pallemaerts, M., Ed.; Europa Law Publishing: Groningen, The Netherlands, 2011.

3. Desmet, E. Indigenous Rights Entwined with Nature Conservation; Intersentia Ltd.: Antwerp, Belgium, 2011. 
4. Brunnee, J. Climate change, global environmental justice and international environmental law. In Environmental Law and Justice in Context; Ebbesson, J., Okowa, P., Eds.; Cambridge University Press: Cambridge, UK, 2009.

5. Stec, S. Chapter 3: Access to Justice in Environmental Matters. Doors to Democracy: a Pan-European Assessment of Current Trends and Practices in Public Participation in Environmental Matters; The Regional Environmental Center for Central and Eastern Europe: Szentendre, Hungary, 1998. Available online: http:/ / archive.rec. org/REC/Publications/PPDoors/EUROPE/Justice.html (accessed on 25 November 2013).

6. Du, Q. Public participation and the challenges of environmental justice in China. In Environmental Law and Justice in Context; Ebbesson, J., Okowa, P., Eds.; Cambridge University Press: Cambridge, UK, 2009.

7. Edmonds, R.L. Patterns of China's Lost Harmony: A Survey of the Country's Environmental Degradation and Protection; Routledge: London, UK, 1994.

8. Zhou, S.X. Forestry in China: Historical Transitions and Industry Developments; Thomson Learning: Singapore, 2006.

9. Beyer, S. Environmental law and policy in the people's republic of China. Chinese J. Int. Law 2006, 5, 185. [CrossRef]

10. Shelton, D.; Kiss, A. Judicial Handbook on Environmental Law; UNEP: Nairobi, Kenya, 2005.

11. The "Constitution of the People's Republic of China" was adopted in 1982 and newly amended on 14 March 2004. Available online: http:/ / www.for68.com/new/201007/he60492159127010212383.shtml (accessed on 3 December 2017). (In Chinese)

12. Article 6 of the "Environmental Protection Law of the People's Republic of China" (1989 version) is the similar with Article 6 of the "Environmental Protection Law of the People's Republic of China" (2014 version). The Article 6 says "All units and individuals shall have the obligation to protect the environment. Local people's governments at various levels shall be responsible for the environmental quality within areas under their jurisdiction. Enterprises, public institutions and any other producers/business operators shall prevent and reduce environmental pollution and ecological destruction, and shall bear the liability for their damage caused by them in accordance with the law. Citizens shall enhance environmental protection awareness, adopt low-carbon and energy-saving lifestyle, and conscientiously fulfill the obligation of environmental protection." The "Environmental Protection Law of the People's Republic of China" (2014 version) was modified based on the "Environmental Protection Law of the People's Republic of China" (1989 version) on 24 April 2014 and shall enter into force since 1 January 2015. Available online: http: / / edu.sina.com.cn/en/2014-05-20/144680376.shtml (accessed on 4 April 2018). (In Chinese)

13. Zhang, S.J.; Lu, L. On legal guarantee for realization of access to justice in environmental matters: Some ideas on improving Article 6 in 'Environmental Protection Law of the People's Republic of China'. 2006. Available online: http:/ / www.procedurallaw.cn/msss/zdwz/200807/t20080724_49656.html (accessed on 5 March 2018). (In Chinese)

14. The "Marine Environmental Protection Law of the People's Republic of China" was adopted on 23 August 1982 and revised on 25 December 1999, Article 3 of the 1982 version and Article 4 of the 1999 version have the similar provision on environmental citizen suits. Available online: http:/ / www.mlr.gov.cn/mlrenglish/ laws/200710/t20071012_656329.htm (accessed on 25 November 2017). (In Chinese)

15. The "Water Pollution Prevention and Control Law of the People's Republic of China" was issued on 11 May 1984 and amended on 28 February 2008 and entered into force on 1 June 2008. Available online: http:/ / www.lawinfochina.com/display.aspx?lib=law\&id=6722 (accessed on 11 August 2017). (In Chinese)

16. The "Law of the People's Republic of China on the Prevention and Control of Atmospheric Pollution" was issued in 1987 and revised on 29 April 2000. Available online: http:/ / www.lawinfochina.com/display.aspx? lib=law\&id=6722 (accessed on 21 November 2017). (In Chinese)

17. The "Law of the People's Republic of China on Prevention of Environmental Pollution Caused by Solid Waste" was issued in 1995 amended on 29 December 2004 and effective on 1 April 2005. Available online: http:/ / www.lawinfochina.com/display.aspx?lib=law\&id=119 (accessed on 3 December 2017). (In Chinese)

18. The "Law of the People's Republic of China on Prevention and Control of Pollution from Environmental Noise" was issued on 29 October 1996 and entered into effective on 1 March 1997. Available online: http:/ / www.lawinfochina.com/display.aspx?lib=law\&id=544 (accessed on 9 August 2018). (In Chinese)

19. The "People's Republic of China Law on the Prevention and Control of Radioactive Pollution" was adopted on 28 June 2003 and entered into effective on 1 October 2003. Available online: http:/ /www.china.org.cn/ 
china/LegislationsForm2001-2010/2011-02/14/content_21915263.htm (accessed on 21 November 2017). (In Chinese)

20. The "Environmental Protection Law of the People's Republic of China" was promulgated by Order No. 22 of the President of the People's Republic of China on December 26, 1989, and was effective on the date of promulgation; it was newly modified on 24 April 2014 and shall enter into force since 1 January 2015. Available online: http:/ / edu.sina.com.cn/en/2014-05-20/144680376.shtml (accessed on 30 June 2018). (In Chinese)

21. The "Measures on Right to Participation in Environmental Protection" was issued by the department of environmental protection on 2 July 2015 and it shall enter into force on 1 September 2015. Available online: http:/ / www.zhb.gov.cn/gkml/hbb/bl/201507/t20150720_306928.htm (accessed on 1 October 2018). (In Chinese)

22. The "General Principles of the Civil Law of the People's Republic of China" was adopted in 1986 and entered into force on 1 January 1987. Available online: http:/ / www.china.com.cn/policy/txt/2012-01/14/content_ 24405953.htm (accessed on 22 November 2017). (In Chinese)

23. The "Civil Procedural Law of the People's Republic of China" was adopted on 9 April 1991 and amended on 31 August 2012. Available online: http:/ / www.kd325.com/ShowArticle.shtml?ID=201051016355390786.htm (accessed on 22 November 2017). (In Chinese)

24. Wang, X.G. Beck's theory of risk society and its implications. Hebei Law Science 2007, 1, 9-10. (In Chinese)

25. Qi, D. Access to Environmental Justice: Environmental Groups Participating in Environmental Public Interest Litigation. Master Thesis, Fudan University, Shanghai, China, 30 May 2012. (In Chinese)

26. Article 55, the "Civil Procedural Law of the People's Republic of China" was adopted on 9 April 1991 and amended on 31 August 2012. (In Chinese).

27. Qi, S.J.; Zhou, Y.Y. Judicial reforms and access to justice: after civil procedural law amended. J. Heilongjiang Administr. Cadre Coll. Politi. Law 2013, 1, 4-5. (In Chinese)

28. Zhang, Y.R. Promoting Environmental Protection through Environmental Civil Public Interest Litigation. Published on 25 January 2013. Available online: http://theory.people.com.cn/n/2013/0125/c4053120326493.html (accessed on 13 November 2017). (In Chinese)

29. The "Administrative Procedural Law of the People's Republic of China" was adopted on 4 April 1989 and entered into effective on 1 October 1990. Available online: http:/ / www.law-lib.com/law/law_view.asp?id= 5641 (accessed on 22 November 2017). (In Chinese)

30. A "specific" administrative act is that administrative authority makes a unilateral act for a "specific" citizen, legal person and other organization on their rights and obligations. The "specific" administrative act could be categorized as "the act to create a right or obligation, including empowering a right or ability"; "the act to deprive or limit right or the act to revoke obligation"; "the act to change right or obligation"; "omission (dereliction of duty).". Available online: http://www.chinabaike.com/law/zhishi/1008/1506894.html (accessed on 27 December 2017). (In Chinese)

31. The "National Human Rights Action Plan of China (2012-2015)" was issued by Information Office of the State Council of the People's Republic of China in June 2012. Available online: http:/ / www.hrol.org/Documents / ChinaDocs/Reports/2012-12/2982.html (accessed on 22 November 2013). (In Chinese and in English) It is only an action plan issued by the State Council, but it works as a guidance document for solving the relevant issues. It is also a remarkable step to show the progress that Chinese government has been made..

32. "The Supreme People's Court Issue Judicial Interpretations on Environmental Public Interests", Gongyi News, 15 January 2015. Available online: http://gongyi.sina.com.cn/gyzx/2015-01-15/095851242.html (accessed on 20 December 2017). (In Chinese)

33. The Ministry of Environmental Protection was replaced by the Ministry of Ecology and Environment of the People's Republic of China according to the "Institutional Reform Plan for the State Council" approved by the 13th session of the National People's Congress Conference in March 2018.

34. The "Interpretation of the Supreme People's Court on Application of 'Civil Procedure Law of the People's Republic of China'" was issued on 18 December 2014 and entered into force on 4 February 2015. Available online: http:/ / www.court.gov.cn/zixun-xiangqing-13241.html (accessed on 24 February 2018). (In Chinese) 
35. The "Opinions of the Supreme People's Court on Comprehensively Deepening the Reform of the People's Court: the Fourth Five Year Outline of the People's Court (2014-2018)" was released on 26 February 2015. Available online: http:/ / www.court.gov.cn/zixun-xiangqing-13520.html (accessed on 24 February 2018). (In Chinese)

36. The "Opinions of the Supreme People's Prosecutors' Office on Deepening the Reform of Prosecutorial Work (2013-2017 Years' Work Plan)" was released on 26 February 2015. Available online: http:/ /www.spp.gov.cn/ zdgz/201502/t20150226_91571.shtml (accessed on 26 February 2018). (In Chinese)

37. The "Pilot Program for Public Interest Litigation Brought by the Prosecutorial Authorities" was issued by the prosecutorial authorities on 2 July 2015. Available online: http:/ / www.spp.gov.cn/zdgz/201507/t20150703_ 100706.shtml (accessed on 26 February 2018). (In Chinese)

38. The "Decision of the Standing Committee of the National People's Congress on Authorizing the Supreme People's Prosecutors' Office to Carry Out Pilot Projects for Public Interest Litigation in Some Areas" was released on 1 July 2015. Available online: http:/ / www.npc.gov.cn/wxzl/gongbao/2015-08/27/content_ 1946100.htm (accessed on 25 February 2018). (In Chinese)

39. The "Measures for the Implementation of the Pilot Program of Initiating Public Interest Actions by the People's Prosecutors' Office" was released on 24 December 2015 and entered into force on 24 December 2015. Available online: http:/ / www.xinhuanet.com/legal/2016-01/07/c_128604511.htm (accessed on 24 March 2018). (In Chinese)

40. The Prosecutorial Authorities in Sichuan Strengthen to Deal with Environmental Public Interest Litigations. Legal Daily. Available online: http:/ / www.legaldaily.com.cn/index/content/2017-12/24/content_7428794. htm?node=20908 (accessed on 24 December 2017). (In Chinese)

41. The "Decision on Amending the 'Civil Procedure Law of the People's Republic of China' and the 'Administrative Litigation Law of the People's Republic of China' by the standing committee of the National People's Congress" was passed by the 28th Conference of the twelfth session of the standing committee of the National People's Congress on 27 June, 2017. This “Decision” would be entered into force on 1 July, 2017. People's Daily, 28 June 2017; 4.

42. The "Guiyang Regulations on Promoting Ecological Civilization Construction" was issued on 8 January 2010. Available online: http:/ / www.ghb.gov.cn/doc/201029/52054307.shtml (accessed on 8 February 2012). (In Chinese)

43. Guiyang: Environmental NGOs may bring cases for inaction of the government concerning the environmental and resources. 15 January 2010. Xinhuang net. Available online: http:/ / www3.xinhuanet. com/chinanews/2010-01/15/content_18777895.htm (accessed on 6 September 2018). (In Chinese)

44. Legal Blog: Judicial Studies. Access to justice in China. Published on 7 November 2008. Available online: http:/ / seiya.fyfz.cn/b/659795 (accessed on 18 November 2018).

45. The environment and resource tribunal was newly established at the supreme People's Court: its name has been changed for several times. Wangyi News. Available online: http:/ /news.163.com/14/0630/09/ 9VVQHKB600014AED.html (accessed on 30 June 2014). (In Chinese)

46. The Supreme People's Court issued the white paper on "China's Environmental Resources Trial (2016-2017)" on 13 July 2017. Available online: https:/ / www.sohu.com/a/156765917_170817 (accessed on 23 July 2018). (In Chinese)

47. Cai, Shouqiu. On strengthening the construction for environmental court. Res. Front Issues Environ. Law 2012, 1, 24-39. (In Chinese)

48. Pan, Y. Reflections on Chinese Environmental Problems. Posted on the website of the Ministry of Environmental Protection of the People's Republic of China. 12 December 2006. Available online: http: / / www.sepa.gov.cn/info/ldjh/200701/t20070118_99754.htm (accessed on 22 November 2013). (In Chinese)

49. Wu, W.Z. Safeguarding a right in environmental issues urgently needs to find a way out. People's Daily, 22 January 2008. (In Chinese)

50. Wang, A. The role of law in environmental protection in China: Recent developments. Vermont J. Environ. Law 2006, 195, 204-205.

51. Goelz, J.D. China's environmental problems: Is a specialized court the solution? Pac. Rim Law Policy J. Assoc. 2009, 10, 155-187. 
52. China resolves pollution case, avoids suit. The Washington Times. 2 September 2009. Available online: http: / / www.washingtontimes.com/news/2009/sep/02/china-resolves-pollution-case-avoids-suit (accessed on 14 November 2013). It discussed that the Qingzhen Municipal People's Court was established to face "growing public concern about the health effects of widespread pollution stemming from China's rapid economic growth".

53. Robinson, N.A. Ensuring access to justice through environmental courts. Pace Environ. Law Rev. 2012, 29, 369-374.

54. All-China Environment Federation is an official environmental organization with a goal to guaranteeing public environmental rights and interests. Available online: http:/ /www.baike.com/wiki/\%E7\%8E\%AF\% $\mathrm{E} 4 \% \mathrm{BF} \% 9 \mathrm{D} \% \mathrm{E} 4 \% \mathrm{~B} 8 \% \mathrm{AD} \% \mathrm{E} 5 \% 9 \mathrm{~B} \% \mathrm{BD}$ (accessed on 22 November 2017).

55. All-China Environment Federation (ACEF) v. Jiangyin Container Ltd., The Intermediate People's Court in Wuxi City of Jiangsu Province. 6 July 2009. Available online: http://blog.voc.com.cn/blog.php?do= showone\&type=blog\&itemid=726395 (accessed on 22 October 2017). (In Chinese)

56. Gao, X.Y. The obstacles and strategies for Chinese environmental NGOs participating environmental public interest litigation. 12 December 2012. Available online: http:/ /www.hicourt.gov.cn/theory/artilce_list.asp? id=7578\&l_class $=4$ (accessed on 23 November 2017). (In Chinese)

57. Zhang, X. Who should hold the key for an environmental litigation? Leg. Dly. 2005, 11, 6. (In Chinese)

58. "Friends of Nature" vs. a mining company in Nanping City, Fujian province (Nanping Case). This mining company destroyed forest in Nanping City, Fujian province. The environmental NGOs ("Friends of Nature") sued this mining company in the people's court in Nanping City, Fujian province on 1 January 2015 when the newly revised environmental law entered into force. It was accepted by the people's court in Nanping City, Fujian province.

59. Xie, W. Research on the connotation of the concept of environmental litigious right. Collect. Pap. Natl. Semin. Environ. Law 2006, 1, 268-275. (In Chinese)

60. Public participation and sustainable development on-line module. Available online: http://www.docstoc. com/docs / 44508222/Public-Participation-and-Sustainable-Development-On-Line-Module (accessed on 25 October 2013).

61. The fourth plenary session of the 18th central committee passed the "Decision of the CPC Central Committee to Comprehensively Advance the Rule of Law on some Major Issues". The "Implementation Measures for the Pilot Program for Public Interest System Brought by the People's Prosecutors' Office", issued by the Supreme People's Prosecutors' Office, addresses the litigious right of the People's Prosecutors' Office.

62. According to Article 5 of the "Marine Environmental Protection Law of the People's Republic of China", "the authorities who is in charge of sea protection", which are the only legal institutions, have the litigious right regarding marine environmental protection.

63. For instance, Environmental Protection Agency in Kunming vs. Sannong Agriculture and Animal Husbandry Limited Company and Kunming Yangpu Joint Animal Husbandry (2010); Environmental Protection Agency in Hancheng City, Shanxi Province vs. Hancheng Alum Mining Industry Limited Company (2012).

64. For instance, "Two Lakes and One Reservoir" Management Bureau in Guiyang City vs. Tianfeng Chemical Company (2007); The Bureau of Land Resources in Anning City vs. Xiangwang Dai and the Other Five Persons (2011); National Protected Areas Management Bureau in Hainan Dongzhai Harbor vs. Mr. Li (2012).

65. For instance, Cai Changhai vs. Long Xingguang, Manager in the roofing waterproof glue factory (2012). The reason why Cai Changhai has a legal standing for the environmental litigation is that Cai Changhai is a volunteer in river protection and he is in charge of this part of river protection. Available online: http:/ / www.lawlib.com/fzdt/newshtml/gzaj/20120927095803.htm (accessed on 14 November 2018).

66. For instance, All-China Environment Federation vs. The Jiangyin Container Ltd. in Jiangsu Province (2009); All-China Environment Federation vs. The Land Resources Bureau in Qingzhen city in Guizhou province (2009); All-China Environment Federation vs. Paper Mill in Wudang area, Guiyang City (2010); All-China Environment Federation vs. Baolu Dyeing Factory, Environmental Health Management Office in Beitang area, Wuxi City and Huishan Water Ltd. (2010); Environmental Charity Association in Changzhou City vs. Mr. Gao (2012).

67. For instance, The People's Government in Danzhao Area in Foshan City vs. Tianyi Group co., Ltd., Guohua Suandyongyou Guo (2009); The People's Government in Xinyi City vs. Baoyuan Mining Limited Company in Xinyi City and Zijin Mining Co. Ltd. in Xinyi City (2010). 
68. Gong, G. Empirical analysis on environmental civil public interest litigation in 2015 in China. Law 2016, 9, 16-33. (In Chinese)

69. The "Interpretation of the Supreme People's Court on the Application of the Relevant Laws in Environmental Civil Public Interest Litigation" was issued on 1 January 2015 and entered into force on 7 January 2015. Available online: http:/ / www.court.gov.cn/zixun-xiangqing-13025.html (accessed on 24 February 2018). (In Chinese)

70. The first environmental public interest litigation on toxic running tracks was accepted. Guiyang News. Published on 1 August 2016. Available online: http:/ / www.gywb.cn/content/201607/22/content_5114448. Htm (accessed on 25 May 2018). (In Chinese)

71. For instance, China Biodiversity Conservation and Green Development Foundation vs. The People's Government in LongDe County, the Ningxia Hui Autonomous Region and other Seven Defendants.

72. For instance, China Biodiversity Conservation and Green Development Foundation vs. Kangfei Fossil Oil China Limited Company and CNOOC (China National Offshore Oil Corporation)

73. For instance, China Biodiversity Conservation and Green Development Foundation vs. Volkswagen China Sales Company.

74. For instance, China Biodiversity Conservation and Green Development Foundation vs. The eight defendants.

75. For instance, China Biodiversity Conservation and Green Development Foundation vs. The Yalong River Basin Hydropower Development Company.

76. The "Measures on the Payment of Litigation costs in People's Republic of China" was issued on 8 December 2006 and entered into force on 1 April 2007.

77. Interpretation from the Supreme People's Court and the Supreme People's Prosecutors' Office on Some Issues of Applicable Law for Supervising Public Interests Cases was issued on 23 February, 2018 and entered into force on 2 March. 2018. Available online: http:/ / www.spp.gov.cn/spp/zdgz/201803/t20180303_368652. shtml (accessed on 18 March 2018). (In Chinese)

78. He, M. Access to justice in the newly revised environmental protection law in china: when theory meets practice. ICUN Acad. Environ. Law e-J. 2015, 6, 163-169.

79. Deng, X.Y. Criticism on the principle of "interest interrelation": Analysis on the plaintiff qualification in environmental litigation. J. Henan Normal Univ. (Philos. Soc. Sci. Ed.). 2009, 4, 13. (In Chinese)

80. Zeng, R. The real obstacle and practical path for Chinese environmental judicial activism. J. Henan Univ. Econo. Law 2014, 3, 152-157. (In Chinese)

81. Zhao, H.X.; Qu, F.T.; Zhu, P.; Shi, X.P. Resource and environmental issues in transitional China: A perspective from the interaction among market, government and society. Chin. J. Popul. Resour. Environ. 2010, 8, 13-23.

82. He, M. A Human Rights-based Approach to Conserving Protected Areas in China: Lessons from Europe. Intersentia Ltd.: Cambridge, UK, 2016.

83. The Rights Practice: Partnerships for Rights and Justice. Improving Access to Justice. Available online: http:/ / www.rights-practice.org/en/programmes/access.html (accessed on 22 August 2014).

84. Wang, H. Stakeholder dialogue as an institutional strategy for sustainable development in China: The case of community environmental round-tables. The World Bank Development Research Group Environment and Energy Team. 2011. Available online: http:/ /www-wds.worldbank.org/external/default/ WDSContentServer/IW3P/IB/2011/08/15/000158349_20110815113133/Rendered/PDF/WPS5759.pdf (accessed on 21 October 2018).

85. United States. Congressional-Executive Commission on China. (2004). Access to Justice in China: Round-table before the Congressional-Executive Commission on China. One Hundred Eighth Congress, second session, 12 July 2004. Government Printing Office: Washington D.C., USA. Available online: http: / / babel.hathitrust.org/cgi/pt?id=umn.31951d024064594;view=1up;seq=11 (accessed on 18 November 2018).

86. Detail information. Available online: http://www.chianlegalaid.gov.cn (accessed on 18 November 2018).

87. Wang, C.F. The role of environmental litigation in protecting environmental rights and improving environment. The Workshop on Business, Human Rights and Access to Justice in China, Hong Kong, 5-6 March 2010; March 2010.

88. ICJ (International Commission of Jurists). Access to Justice: Human Rights Abuses Involving Corporations_People's Republic of China; ICJ: Geneva, Switzerland, 2010; pp. 23-24. Available online: http:// icj.wpengine.netdna-cdn.com/wp-content/uploads/2012/06/China-access-justice-publication-2010.pdf (accessed on 14 November 2013). 
89. 1721 People v. Rongping Chemical Plant (2003). Available online: http://www.fsou.com/html/text/fnl/ 1175258/117525863.html (accessed on 12 December 2017). (In Chinese)

90. According to the exchange rate on 18 November 2018, 1 EUR is equal to 7.9 Yuan. Available online: http:/ / huilv.911cha.com/EURCNY.html (accessed on 18 November 2018).

91. Li, Z.Q. Research on the establishment of the fund system for environmental public interest litigation in China. Master Thesis, East China University of Science and Technology, Shanghai, China, 30 May 2008. (In Chinese)

92. Ren, S. Environmental public interest litigation may apply for the fund support. Jinghua Times 2015, 1, c02. (In Chinese)

93. Eberle, J.E. The method and role of comparative law. Wash. Univer. Glob. Stud. Law Rev. 2009, 8, pp. $451-486$. Available online: http:/ /law.wustl.edu/WUGSLR/Issues/Volume8_3/Eberle.pdf (accessed on 7 May 2018).

94. Confucianism is an ethical and philosophical system developed from the teachings of the Chinese philosopher Confucius (551-479 B.C.). "Li" is one of the basic virtues promoted by Confucius, " $\mathrm{Li}^{\prime}$ means to achieve "the preservation of natural harmony (achieved through mediation)", some typical ideas such as "It is better to keep a friend than to win a lawsuit". Available online: http://www.mrrena.com/misc/gier_ _dancing_ru.php (accessed on 21 November 2017).

95. Legalism that had arisen during the early Warring State period (475-221B.C.) advocated strict obedience to the legal system, which was in direct conflict with Confucian ideals. In the legalistic view, human beings are naturally greedy and selfish. Available online: http:/ / www.oocities.org/stenrose_och_teg/Kinas_dyn.htm (accessed on 21 November 2017).

96. Taoism that had arisen during the Han Dynasty (206-220 B.C.) is a philosophical and religious tradition that emphasizes living in harmony. The ambiguous term "wu-wei" constitutes the leading ethical concept in Taoism. "Wu-wei" means "action without action", that is to say, the universe works harmoniously according to its own ways, a potentially harmful interference is to be avoided, and in this way, goals can be achieved effortlessly. Available online: http:/ / enlight.lib.ntu.edu.tw / FULLTEXT/JR-PHIL/ew27139.htmandhttp: / /home.wlu.edu/ \{\}lubint/Touchstone/Acupuncture-Valeri.htm (accessed on 21 November 2017).

97. Wu, J.K. Chinese traditional no litigation ideas and harmony society construction. Enterprise Civilization 2007, 10, 69. (In Chinese)

98. Hu, W.L. Exploration and practice of public interest litigation in China. The website of Research Center for Government by Law. 24 October 2018. Available online: http:/ / fzzfyjy.cupl.edu.cn/info/1021/9427.htm (accessed on 21 November 2018). (In Chinese) 